Louisiana State University

LSU Digital Commons

$11-19-2019$

\title{
Simultaneous Enhancement of Near-Infrared Emission and Dye Photodegradation in a Racemic Aspartic Acid Compound via Metal-Ion Modification
}

Frank R. Fronczek

Louisiana State Univ, Dept Chem

Jian Xu

Louisiana State Univ, Div Elect \& Comp Engn

Follow this and additional works at: https://digitalcommons.Isu.edu/chemistry_pubs

Part of the Chemistry Commons

\section{Recommended Citation}

Fronczek, Frank R. and Xu, Jian, "Simultaneous Enhancement of Near-Infrared Emission and Dye Photodegradation in a Racemic Aspartic Acid Compound via Metal-Ion Modification" (2019). Faculty Publications. 41.

https://digitalcommons.Isu.edu/chemistry_pubs/41

This Article is brought to you for free and open access by the Department of Chemistry at LSU Digital Commons. It has been accepted for inclusion in Faculty Publications by an authorized administrator of LSU Digital Commons. For more information, please contact gcoste1@lsu.edu. 


\section{Simultaneous Enhancement of Near-Infrared Emission and Dye Photodegradation in a Racemic Aspartic Acid Compound via Metal- Ion Modification}

Ye Wu, ${ }^{\dagger, \nabla}$ Pengfei Ou, ${ }^{\ddagger, \nabla}$ Frank R. Fronczek, ${ }^{\S, \nabla}{ }^{\circledR}$ Jun Song, ${ }^{\ddagger \odot}$ Yingcheng Lin, ${ }^{*, \perp}$ Hui-Min Wen, ${ }^{*, \#}$ and Jian $\mathrm{Xu}^{*}, \|$

${ }^{\dagger}$ School of Electrical and Automation Engineering, Jiangsu Key Laboratory of 3D Printing Equipment and Manufacturing, Nanjing Normal University, Nanjing 210046, P. R. China

${ }^{\ddagger}$ Department of Mining and Materials Engineering, McGill University, Montreal, QC H3A 0C5, Canada

${ }^{\S}$ Department of Chemistry and "Division of Electrical and Computer Engineering, Louisiana State University, Baton Rouge, Louisiana 70803, United States

${ }^{\perp}$ School of Microelectronics and Communication Engineering, Key Laboratory of Dependable Service Computing in Cyber Physical Society (Chongqing University) of Ministry of Education, Chongqing University, Chongqing 400044, China

${ }^{\#}$ College of Chemical Engineering, Zhejiang University of Technology, Zhejiang 310014, P. R. China

Supporting Information
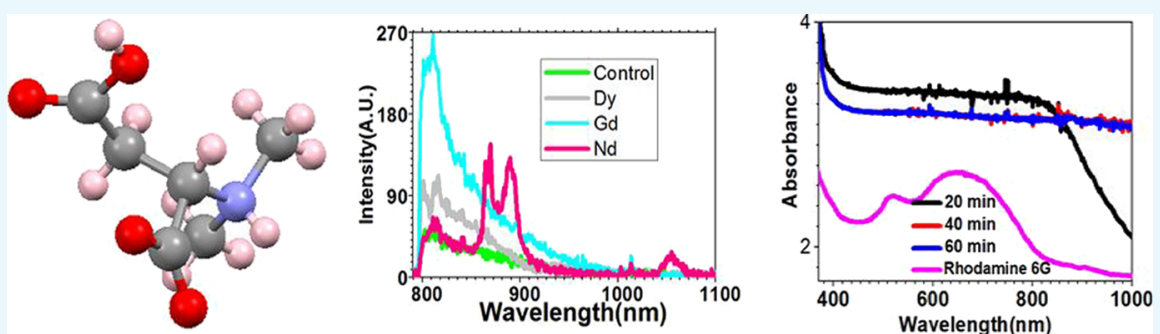

ABSTRACT: Changing functionalities of materials using simple methods is an active area of research, as it is "green" and lowers the developing cost of new products for the enterprises. A new small molecule racemic $N, N$-dimethyl aspartic acid has been prepared. Its structure is determined by single-crystal X-ray diffraction. It is characterized by FTIR, XPS, ${ }^{1} \mathrm{H}$ NMR, and mass spectroscopy. Its near-infrared luminescence can be enhanced by the combination of metal ions, including $\mathrm{Dy}^{3+}, \mathrm{Gd}^{3+}$, $\mathrm{Nd}^{3+}, \mathrm{Er}^{3+}, \mathrm{Sr}^{3+}, \mathrm{Y}^{3+}, \mathrm{Zn}^{2+}, \mathrm{Zr}^{4+}, \mathrm{Ho}^{3+}, \mathrm{Yb}^{3+}, \mathrm{La}^{3+}, \mathrm{Pr}^{6+} / \mathrm{Pr}^{3+}$, and $\mathrm{Sm}^{3+}$ ions. An optical chemistry mechanism upon interaction between the sensitizer and activator is proposed. Furthermore, the association of $\mathrm{Ca}^{2+}, \mathrm{Sr}^{2+}$, or $\mathrm{Zr}^{4+}$ ions to the molecule enhanced its photodegradation for dyes under white-light irradiation. Specifically, rhodamine $6 \mathrm{G}$ can be degraded by the $\mathrm{Ca}^{2+}-$ modified molecule; rhodamine B, rhodamine 6G, and fluorescein sodium salt can be degraded by the $\mathrm{Sr}^{2+}$ - or $\mathrm{Zr}^{4+}$-modified molecule. This surprising development opens a way in simultaneously increasing NIR luminescence and the ability of dye photodegradation for the investigated molecule.

\section{INTRODUCTION}

The development of materials with multifunctionalities is important, which can be used to fulfill different tasks and therefore lower the cost for the enterprises.

One type of functionality we are interested in for the materials is the near-infrared (NIR) emission. Indeed, synthesis of materials with photoluminescence in the NIR window (750$1100 \mathrm{~nm}$ ) has been an active area of research given that their application in biomedical imaging within this region is superior to the ultraviolet-visible range. ${ }^{1-5}$ Much improvement in imaging quality can be achieved due to low levels of tissue autofluorescence, diminished photon scattering, and reduced photon absorption. Several materials systems have been reported to show NIR fluorescence, including semiconductor quantum dots, ${ }^{6,7}$ metal organic complexes, ${ }^{8}$ small molecule dyes, ${ }^{9}$ polymers, ${ }^{10}$ carbon nanotubes, ${ }^{11}$ metal clusters, ${ }^{12}$ and inorganic nanoparticles. ${ }^{13-19}$

One challenge that is associated with the application of NIR fluorophores would be the optimization of the luminescence. Suppose that we have synthesized one NIR fluorophore, can we further increase the NIR fluorescence intensity or shift the center wavelength using some facile methods? This is extremely useful in practical clinic or industry applications where the access to the chemical hood and chemical reactors is limited. Simple and cost-effective ways for modification of the optical properties of the fluorophores are in great demand. One possible way is

Received: July 31, 2019

Accepted: October 29, 2019

Published: November 8, 2019 
using the metal ions to process the synthesized NIR fluorophore. Given that the metal ions have rich energy levels, the optical properties of the materials may be particularly tuned by incorporation of NIR-emissive metal sites such as $\mathrm{Er}^{3+}, \mathrm{Nd}^{3+}$, $\mathrm{Y}^{3+}, \mathrm{La}^{3+}, \mathrm{Pr}^{3+}, \mathrm{Gd}^{3+}, \mathrm{Dy}^{3+}$, and $\mathrm{Yb}^{3+} \cdot{ }^{20-27}$

Another type of functionality in the materials we are looking for is dye degradation. Dyes are extensively used in textile plants for coloring clothes. The dyes that are discharged into the rivers can seriously harm a lot of birds and animals. The dyes create an unsafe environment for them due to their toxicity. Dye molecules generally contain complex aromatic molecular structures that make them more stable and more difficult to biodegrade. It is critical to perform the dye pretreatment for the wastewater as these dye materials would end up in our drinking water if the wastewater is not treated properly. The dyes can be decomposed via photodegradation. Especially, white-light- or solar-light-assisted photodegradation for organic pollutants is considered to be a green technology.

Aspartic acid is an $\alpha$-amino acid that is used in the biosynthesis of proteins. It is industrially made by fermentative or enzymatic batch process from fumaric acid and ammonia, using aspartase as the enzyme. ${ }^{28} \mathrm{~L} / \mathrm{D}$-Aspartate (the ionic form of aspartic acid) is reported to be present in the human brain. ${ }^{29}$

It is rarely reported that aspartic acid and its derivatives are chemically synthesized without using the aspartase enzyme. No reports about them have shown NIR fluorescence as well as dyephotodegradation effects.

Herein, we first report chemical synthesis of a new type of aspartic acid single crystal: racemic $N, N$-dimethyl aspartic acid (compound 1). The scheme is shown in Scheme 1. Here, fumaric acid is utilized as one of the raw materials for making compound $\mathbf{1}$.

\section{Scheme 1. Synthetic Route of Racemic N,N-Dimethyl} Aspartic Acid

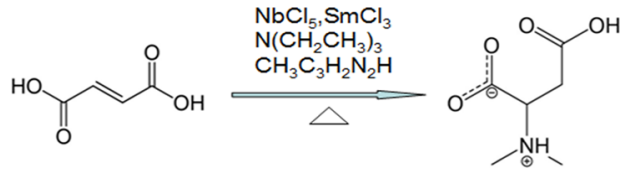

Compound $\mathbf{1}$ was characterized by single-crystal X-ray diffraction, X-ray photoelectron spectroscopy (XPS), ${ }^{1} \mathrm{H}$ nuclear magnetic resonance (NMR) spectroscopy, Fourier transform infrared (FTIR) spectroscopy, and mass spectroscopy.

Compound 1 shows NIR fluorescence in the range of $800-$ $1100 \mathrm{~nm}$ when it is excited by $785 \mathrm{~nm}$ light. It can be modified by the metal ions to increase the fluorescence intensity as well as to shift the peak wavelength. Its NIR photoluminescence corresponding to the $785 \mathrm{~nm}$ light excitation can be tuned by combination of different metal ions, including $\mathrm{Dy}^{3+}, \mathrm{Gd}^{3+}, \mathrm{Nd}^{3+}$, $\mathrm{Er}^{3+}, \mathrm{Sr}^{2+}, \mathrm{Tl}^{3+}, \mathrm{Y}^{3+}, \mathrm{Zn}^{2+}, \mathrm{Zr}^{4+}, \mathrm{Ho}^{3+}, \mathrm{Yb}^{3+}, \mathrm{La}^{3+}, \mathrm{Pr}^{6+} / \mathrm{Pr}^{3+}, \mathrm{Sm}^{3+}$, $\mathrm{Ag}^{+}, \mathrm{Ce}^{4+}, \mathrm{Cr}^{3+}, \mathrm{Cs}^{+}, \mathrm{In}^{+}, \mathrm{Li}^{+}, \mathrm{Mo}^{6+}, \mathrm{Na}^{+}, \mathrm{Ni}^{3+}$, and $\mathrm{Rb}^{+}$ions. The introduction of $\mathrm{Dy}^{3+}, \mathrm{Gd}^{3+}, \mathrm{Nd}^{3+}, \mathrm{Er}^{3+}, \mathrm{Sr}^{2+}, \mathrm{Tl}^{3+}, \mathrm{Y}^{3+}, \mathrm{Zn}^{2+}, \mathrm{Zr}^{4+}$, $\mathrm{Ho}^{3+}, \mathrm{Yb}^{3+}, \mathrm{La}^{3+}, \mathrm{Pr}^{6+} / \mathrm{Pr}^{3+}$, and $\mathrm{Sm}^{3+}$ to the molecule leads to an enhanced NIR photoluminescence band centered around 813 $\mathrm{nm}$. Furthermore, the introduction of $\mathrm{Nd}^{3+}$ to this molecule leads to intensified NIR photoluminescence bands at 812.36 , 868.86, 888.31, 1014.14, and $1055.68 \mathrm{~nm}$.

Additionally, metal-ion modification of the studied molecule leads to the enhanced dye photodegradation. Here, $\mathrm{Ca}^{2+}$ modified $N, N$-dimethyl aspartic acid (compound 2) can be used for photodegradation of rhodamine $6 \mathrm{G}$ under white-light irradiation. Both $\mathrm{Zr}^{4+}$-modified $\mathrm{N}, \mathrm{N}$-dimethyl aspartic acid (compound 3) and $\mathrm{Sr}^{2+}$-modified $\mathrm{N}, \mathrm{N}$-dimethyl aspartic acid (compound 4) can be applied for photodegradation of rhodamine $6 \mathrm{G}$, rhodamine $\mathrm{B}$, and fluorescein sodium salt under white-light irradiation.

The significance of the metal-ion modification for compound 1 is supported by the enhancement of the NIR fluorescence and dye photodegradation.

\section{RESULTS AND DISCUSSION}

2.1. Single-Crystal X-ray Diffraction. Single-crystal X-ray diffraction indicated that compound $\mathbf{1}$ crystallizes in the space group $P 21 / c$. As depicted in Figure 1, its structure is similar to L-

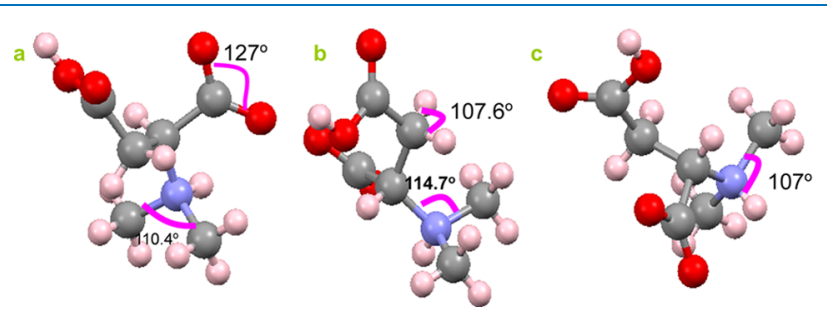

Figure 1. Single-crystal structures of racemic $\mathrm{N}, \mathrm{N}$-dimethyl aspartic acid (black sphere: carbon atom; pink sphere: hydrogen atom; red sphere: oxygen atom; blue sphere: nitrogen atom) are viewed from different axes: (a) $a$ axis; (b) $b$ axis; (c) $c$ axis.

aspartic acid, but with two methyl groups on the $\mathrm{N}$ atom. It exists in the solid state as a zwitterion, with one $\mathrm{H}$ atom transferring from $\mathrm{COOH}$ to the $\mathrm{N}$ atom. The lattice parameters are described in Table 1.

Table 1. Crystal Data of Racemic N,N-Dimethyl Aspartic Acid

$\begin{array}{ll}\text { chemical formula } & \mathrm{C}_{6} \mathrm{H}_{11} \mathrm{NO}_{4} \\ \text { CCDC deposition number } & \mathrm{CCDC} 1904827 \\ \text { chemical name } & \text { racemic } N, N \text {-dimethyl aspartic acid } \\ \text { chemical formula weight } & 161.16 \\ \text { crystal system } & \text { monoclinic } \\ \text { space group } & P 21 / c \\ \text { a }(\AA) & 6.2704(8) \\ \mathrm{b}(\AA) & 9.9678(11) \\ \text { c }(\AA) & 12.0597(15) \\ \beta\left({ }^{\circ}\right) & 101.205(6) \\ \text { cell volume }\left(\AA^{3}\right) & 739.39(16) \\ \text { cell formula units } Z & 4 \\ \text { temperature }(\mathrm{K}) & 90 \\ \text { radiation } & \mathrm{Mo} \mathrm{K \alpha}(\lambda=0.71073 \AA) \\ \theta \text { limits }\left(^{\circ}\right) & 2.6-25.1 \\ \text { data collected/unique/obsd } & 6132 / 1309 / 1016 \\ R \text { factor } & 0.032 \\ w R \text { factor } & 0.073\end{array}$

2.2. XPS, FTIR, NMR, and Mass Spectroscopy Characterization. Figure 2a shows the high-resolution XPS spectra of $\mathrm{O} 1 \mathrm{~s}$, which reveal two peaks at 531.21 and $532.57 \mathrm{eV}$. They correspond to the $-\mathrm{C}-\mathrm{O}-$ and $-\mathrm{C}-\mathrm{O}-\mathrm{H}-$ bonding, respectively. For C 1s XPS spectra (Figure 2b), three peaks at $284.04,285.19$, and $288.05 \mathrm{eV}$ are observed, which are attributed to $-\mathrm{C}-\mathrm{C}-,-\mathrm{O}-\mathrm{C}-\mathrm{O}-$, and $-\mathrm{C}-\mathrm{H}-\mathrm{N}-$. N $1 \mathrm{~s}$ XPS spectra present two peaks at 399.43 and $401.19 \mathrm{eV}$ (Figure 2c). The $399.43 \mathrm{eV}$ peak is considered to be due to $-\mathrm{H}-\mathrm{N}-$ 

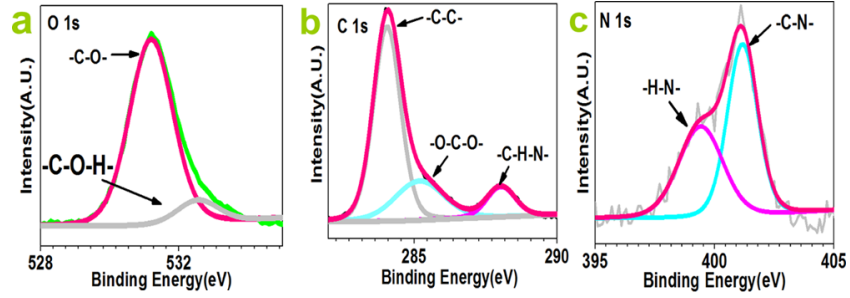

Figure 2. High-resolution XPS spectra: (a) O 1s; (b) C 1s; (c) N 1 s.

bonding, while the $401.19 \mathrm{eV}$ peak is related to $-\mathrm{C}-\mathrm{N}-$ bonding. ${ }^{30-32}$

FTIR spectra (see Figure 3a) present peaks at 676.56, 790.87, 904.48, 958.48, 1030.72, 1060.87, 1180.79, 1307.02, 1372.95,
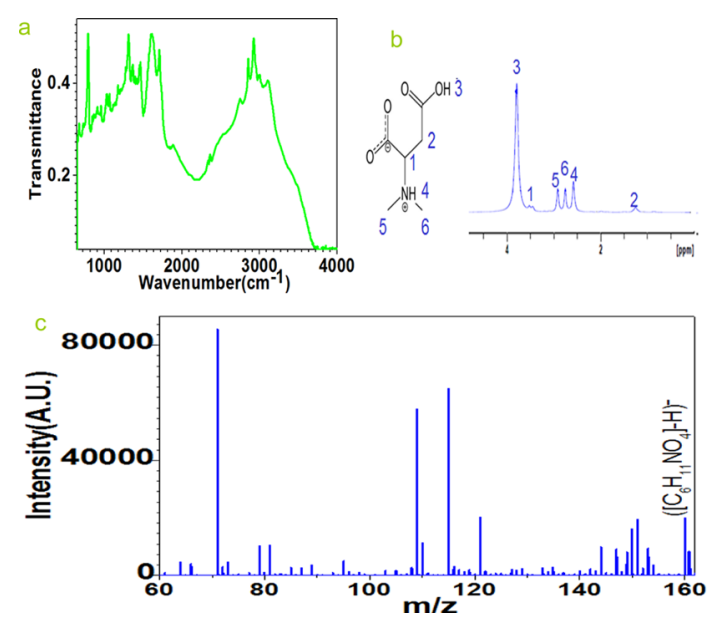

Figure 3. FTIR, NMR, and mass spectroscopy characterization of compound 1: (a) FTIR spectra; (b) ${ }^{1} \mathrm{H}$ NMR with peak labels corresponding to proton locations; (c) mass spectra.

1456.40, 1606.48, 1708.87, 1888.40, 2362.47, 2746.78, 2848.47, $2926.31,2998.55$, and $3118.47 \mathrm{~cm}^{-1}$. The $676.56 \mathrm{~cm}^{-1}$ peak is assigned to $\mathrm{C}-\mathrm{O}-\mathrm{O}-\mathrm{H}$ in-plane bending. The $904.48 \mathrm{~cm}^{-1}$ peak is assigned to $\mathrm{C}-\mathrm{C}$ stretching. The $958.48 \mathrm{~cm}^{-1}$ peak is considered as $-\mathrm{O}-\mathrm{H}-$ out-of-plane bending. The 1030.72 and $1060.87 \mathrm{~cm}^{-1}$ peaks are due to $-\mathrm{C}-\mathrm{N}-$ stretching. The 1180.79 $\mathrm{cm}^{-1}$ peak is considered to be due to $\mathrm{N}-\mathrm{H}$ rocking. The 1307.02 $\mathrm{cm}^{-1}$ peak is assigned to $-\mathrm{CH}_{2}-$ wagging. The $1372.95 \mathrm{~cm}^{-1}$ peak is related to $-\mathrm{CH}-$ in-plane bending. The 1456.40 and $1606.48 \mathrm{~cm}^{-1}$ peaks are attributed to $-\mathrm{COO}-$ stretching. The $1708.87 \mathrm{~cm}^{-1}$ peak corresponds to $\mathrm{C}-\mathrm{O}-$ stretching. The 1888.40, 2362.47, 2746.78, and $2848.47 \mathrm{~cm}^{-1}$ peaks are attributed to the combinational effect of $\mathrm{C}-\mathrm{O}$ stretching, $\mathrm{C}-$ $\mathrm{H}$ stretching, $\mathrm{C}-\mathrm{C}$ stretching, $\mathrm{NH}$ in-plane bending, and $\mathrm{OH}$ inplane bending. The $2926.31 \mathrm{~cm}^{-1}$ peak is assigned to $-\mathrm{CH}_{2}-$ stretching. The $2998.55 \mathrm{~cm}^{-1}$ peak is related to $-\mathrm{OH}-$ stretching. The $3001 \mathrm{~cm}^{-1}$ peak is attributed to $\mathrm{C}-\mathrm{H}$ stretching. The $3118.47 \mathrm{~cm}^{-1}$ peak is due to $\mathrm{N}-\mathrm{H}$ stretching. ${ }^{33}$

${ }^{1} \mathrm{H}$ NMR spectra contain six proton lines at 3.76, 3.49, 2.88, $2.72,2.55$, and $1.22 \mathrm{ppm}$, which are assigned to the groups as labeled in Figure 3b. Mass spectra (see Figure 3c) show the $\left[\left(\mathrm{C}_{6} \mathrm{H}_{11} \mathrm{NO}_{4}-\mathrm{H}\right)\right]^{-}$ion $(160 \mathrm{~m} / z)$ as the major product ion. Other product ions were due to the further loss of $\mathrm{NH}, \mathrm{CH}_{2}$, $\mathrm{NH}-\mathrm{CH}_{3}, \mathrm{COOH}, \mathrm{COOCH}, \mathrm{CH}_{2} \mathrm{CO}, \mathrm{CO}$, and $\mathrm{CO}_{2} \cdot{ }^{34,35}$ The peaks and their corresponding product ions are listed in Table 2.

2.3. Optical Properties. The optical properties of compound $\mathbf{1}$ are studied. Its absorption presents peaks at
Table 2. Mass Spectra of Product Ions for Compound 1

\begin{tabular}{|c|c|}
\hline peaks $(m / z)$ & product ions \\
\hline 147 & {$\left[\left(\mathrm{C}_{6} \mathrm{H}_{11} \mathrm{NO}_{4}-\mathrm{CH}_{2}\right)\right]^{+}$} \\
\hline 146 & {$\left[\left(\mathrm{C}_{6} \mathrm{H}_{11} \mathrm{NO}_{4}-\mathrm{NH}\right)\right]^{+}$} \\
\hline 145 & {$\left[\left(\mathrm{C}_{6} \mathrm{H}_{11} \mathrm{NO}_{4}-\mathrm{CH}_{3}\right)\right]^{+}$} \\
\hline 143 & {$\left[\left(\mathrm{C}_{6} \mathrm{H}_{11} \mathrm{NO}_{4}-\mathrm{H}_{2} \mathrm{O}\right)\right]^{+}$} \\
\hline 133 & {$\left[\left(\mathrm{C}_{6} \mathrm{H}_{11} \mathrm{NO}_{4}-\mathrm{CO}\right)\right]^{+}$} \\
\hline 131 & {$\left[\left(\mathrm{C}_{6} \mathrm{H}_{11} \mathrm{NO}_{4^{-}}\left(\mathrm{NH}+\mathrm{CH}_{3}\right)\right)\right]^{+}$} \\
\hline 119 & {$\left[\left(\mathrm{C}_{6} \mathrm{H}_{11} \mathrm{NO}_{4}-\mathrm{CH}_{2} \mathrm{CO}\right)\right]^{+}$} \\
\hline 117 & {$\left[\left(\mathrm{C}_{6} \mathrm{H}_{11} \mathrm{NO}_{4}-\mathrm{CO}_{2}\right)\right]^{+}$} \\
\hline 116 & {$\left[\left(\mathrm{C}_{6} \mathrm{H}_{11} \mathrm{NO}_{4}-\mathrm{HN}\left(\mathrm{CH}_{3}\right)_{2}\right)\right]^{+}$} \\
\hline 115 & {$\left[\left(\mathrm{C}_{6} \mathrm{H}_{11} \mathrm{NO}_{4^{-}}\left(\mathrm{H}_{2} \mathrm{O}+\mathrm{CO}\right)\right]^{+}\right.$} \\
\hline 104 & {$\left[\left(\mathrm{C}_{6} \mathrm{H}_{11} \mathrm{NO}_{4}-\mathrm{COOCH}\right)\right]^{+}$} \\
\hline 101 & {$\left[\left(\mathrm{C}_{6} \mathrm{H}_{11} \mathrm{NO}_{4}-\mathrm{CH}_{3} \mathrm{COOH}\right)\right]^{+}$} \\
\hline 87 & {$\left[\left(\mathrm{C}_{6} \mathrm{H}_{11} \mathrm{NO}_{4^{-}}\left(\mathrm{COOH}+\mathrm{CH}_{2}+\mathrm{CH}_{3}\right)\right]^{+}\right.$} \\
\hline 83 & {$\left[\left(\mathrm{C}_{6} \mathrm{H}_{11} \mathrm{NO}_{4^{-}}\left(\mathrm{CH}_{3} \mathrm{COOH}+\mathrm{H}_{2} \mathrm{O}\right)\right]^{+}\right.$} \\
\hline 81 & {$\left[\left(\mathrm{C}_{6} \mathrm{H}_{11} \mathrm{NO}_{4^{-}}\left(\mathrm{CH}_{3} \mathrm{COOH}+\mathrm{H}_{2} \mathrm{O}+\mathrm{H}_{2}\right)\right.\right.$} \\
\hline
\end{tabular}

746.4, 877.64, and $980.73 \mathrm{~nm}$ (Figure 4a). The peaks at 746.4 and $877.64 \mathrm{~nm}$ are weak, while the $980.73 \mathrm{~nm}$ peak is strong.

Figure $4 \mathrm{~b}$ shows the fluorescence spectra excited by 280,310 , $320,340,350$, and $360 \mathrm{~nm}$. When the sample is excited by 280 , 310 , and $320 \mathrm{~nm}$ light, the fluorescence shows two peaks at 383 and $523 \mathrm{~nm}$, separately. When it is excited by $340 \mathrm{~nm}$ light, only the $523 \mathrm{~nm}$ peak survives. Green-light emission is observed. When it is excited by 350 and $360 \mathrm{~nm}$, the green-light emission is enhanced. Figure $4 \mathrm{c}$ presents a fluorescence peak at $531.77 \mathrm{~nm}$ when it is excited by $440 \mathrm{~nm}$ light. When it is excited by $540 \mathrm{~nm}$ light, the fluorescence spectra present a peak at $617.73 \mathrm{~nm}$ and a shoulder around $708 \mathrm{~nm}$ (Figure 4d). When it is excited by 610 $\mathrm{nm}$ light, the fluorescence spectra reveal two peaks at 670 and $720 \mathrm{~nm}$ (Figure 4e). When it is excited by $785 \mathrm{~nm}$ light, the emission at $813.18 \mathrm{~nm}$ is observed.

2.4. Enhancement of NIR Fluorescence. NIR fluorescence spectra of compound 1 modified with $\mathrm{Dy}^{3+}, \mathrm{Gd}^{3+}, \mathrm{Nd}^{3+}$, $\mathrm{Er}^{3+}, \mathrm{Sr}^{2+}, \mathrm{Tl}^{3+}, \mathrm{Y}^{3+}, \mathrm{Zn}^{2+}, \mathrm{Zr}^{4+}, \mathrm{Ho}^{3+}, \mathrm{Yb}^{3+}, \mathrm{La}^{3+}, \mathrm{Pr}^{6+} / \mathrm{Pr}^{3+}$, $\mathrm{Sm}^{3+}, \mathrm{Ag}^{+}, \mathrm{Ce}^{4+}, \mathrm{Cr}^{3+}, \mathrm{Cs}^{+}, \mathrm{In}^{+}, \mathrm{Li}^{+}, \mathrm{Mo}^{6+}, \mathrm{Na}^{+}, \mathrm{Ni}^{3+}$, and $\mathrm{Rb}^{+}$ ions have been obtained using a $785 \mathrm{~nm}$ diode, as shown in Figures 5 and 6 . The excitation light was not intensively focused on the samples since the samples may decompose upon large excitation density. Figure 5a depicts the NIR fluorescence of compound 1 modified by $\mathrm{Nd}^{3+}, \mathrm{Gd}^{3+}$, and $\mathrm{Dy}^{3+}$ ions. The sample of compound $\mathbf{1}$ before metal-ion modification only shows a peak at $813.18 \mathrm{~nm}$ whose intensity is considered as $I_{0}$. Surprisingly, the sample that was modified by $\mathrm{Nd}^{3+}$ ions shows several bands at $812.36,868.86,888.31,1014.14$, and $1055.68 \mathrm{~nm}$. The 868.86 $\mathrm{nm}$ peak shows the highest intensity whose intensity is 2 times greater than $I_{0}$. The $\mathrm{Gd}^{3+}$-ion-modified sample shows a peak at $811.25 \mathrm{~nm}$ whose intensity is 4.67 times greater than $I_{0}$. It also shows a weak peak at $1013.55 \mathrm{~nm}$. The $\mathrm{Dy}^{3+}$-ion-modified sample depicts two strong peaks at 800.69 and $816.76 \mathrm{~nm}$ and a weak peak at $1014.14 \mathrm{~nm}$. The intensity of the $816.76 \mathrm{~nm}$ peak is 1.38 times greater than $I_{0}$.

Figure $5 \mathrm{~b}-\mathrm{e}$ plots the fluorescence spectra of the samples modified by $\mathrm{Er}^{3+}, \mathrm{Sr}^{2+}, \mathrm{Tl}^{3+}, \mathrm{Y}^{3+}, \mathrm{Zn}^{2+}, \mathrm{Zr}^{4+}, \mathrm{Ho}^{3+}, \mathrm{Yb}^{3+}, \mathrm{La}^{3+}$, $\mathrm{Pr}^{6+} / \mathrm{Pr}^{3+}$, and $\mathrm{Sm}^{3+}$ ions. They show a profile similar to that of the $\mathrm{Gd}^{3+}$-ion-modified sample. They all present a peak around $810-813 \mathrm{~nm}$ whose intensity is $0.8-2.8$ times higher than $I_{0}$.

The samples modified by $\mathrm{Ce}^{4+}, \mathrm{Cr}^{3+}, \mathrm{Cs}^{+}, \mathrm{In}^{+}, \mathrm{Li}^{+}, \mathrm{Mo}^{6+}, \mathrm{Na}^{+}$, $\mathrm{Ni}^{3+}$, and $\mathrm{Rb}^{+}$ions all show a fluorescence peak whose intensity is comparable to $I_{0}$ (Figure $6 \mathrm{a}-\mathrm{c}$ ). The sample modified by $\mathrm{Ag}^{+}$ ions shows a suppressed fluorescence profile (Figure 6a). The 

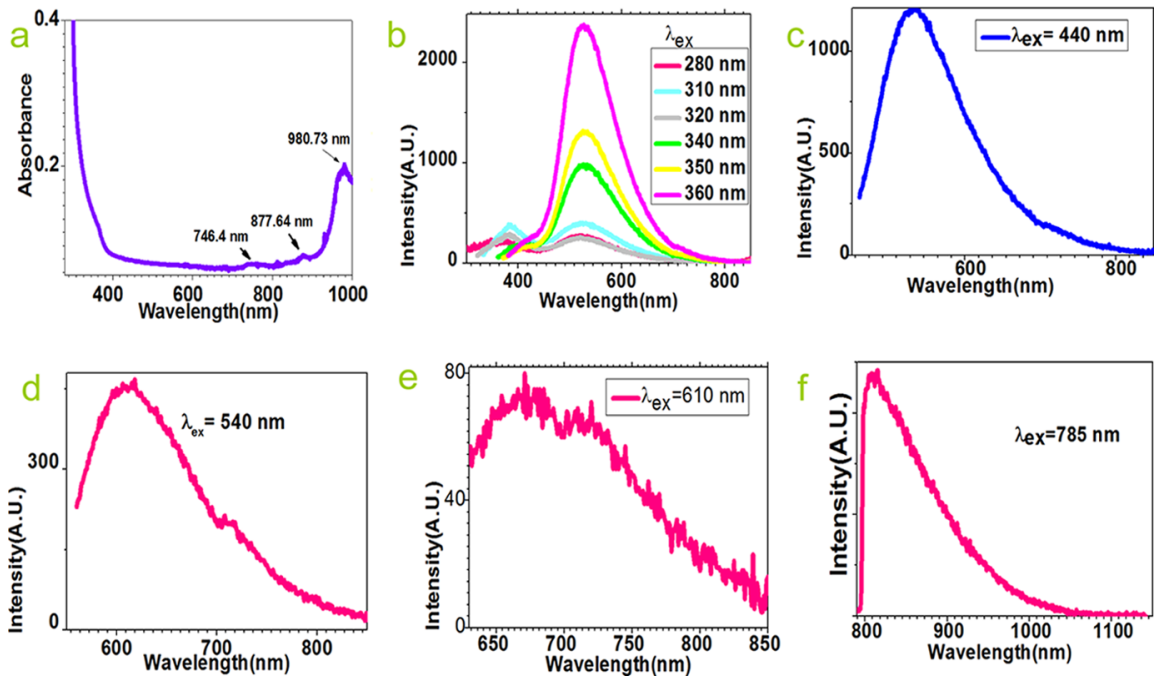

Figure 4. (a) Optical absorption of compound 1. (b) Fluorescence spectra show white-to-green light transition when the excitation light varies between 280 and $360 \mathrm{~nm}$. Polychromatic fluorescence spectra are shown when excited by light sources with various wavelengths: (c) $440 \mathrm{~nm}$; (d) 540 $\mathrm{nm}$; (e) $610 \mathrm{~nm}$; (f) $785 \mathrm{~nm}$.
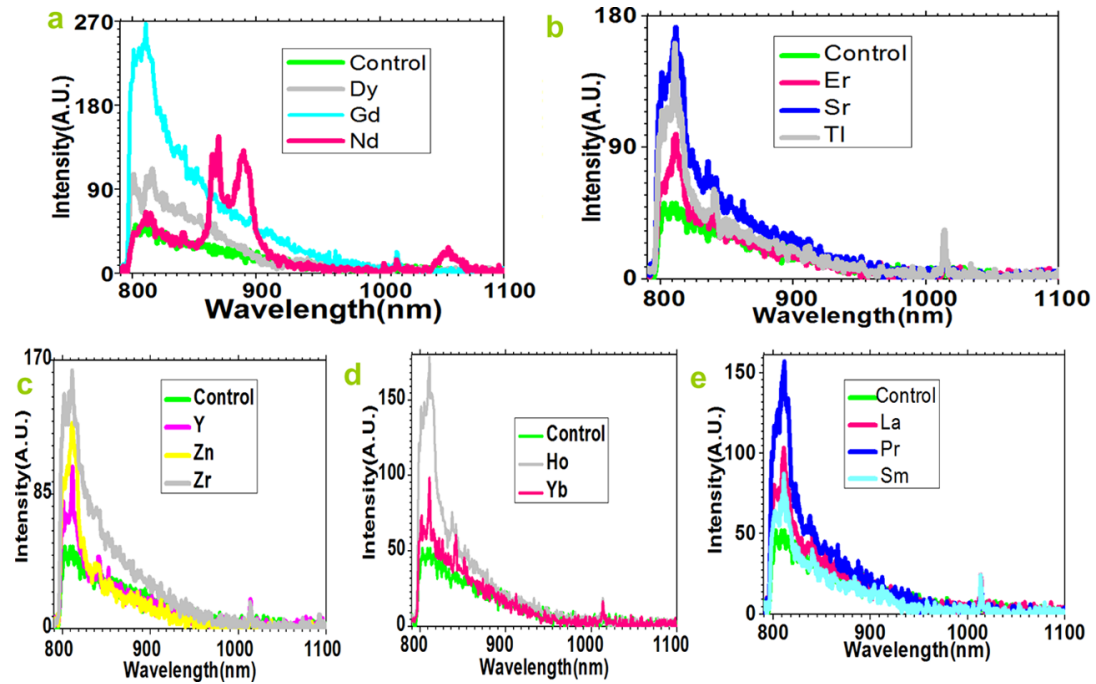

Figure 5. Near-infrared fluorescence of compound 1 could be enhanced by modification with various metal ions: (a) $\mathrm{Dy}^{3+}, \mathrm{Gd}^{3+}, \mathrm{and} \mathrm{Nd}^{3+}$; (b) $\mathrm{Er}^{3+}$, $\mathrm{Sr}^{2+}$, and $\mathrm{Tl}^{3+}$; (c) $\mathrm{Y}^{3+}, \mathrm{Zn}^{2+}$, and $\mathrm{Zr}^{4+}$; (d) $\mathrm{Ho}^{3+}$ and $\mathrm{Yb}^{3+}$; (e) $\mathrm{La}^{3+}, \mathrm{Pr}^{6+} / \mathrm{Pr}^{3+}$, and $\mathrm{Sm}^{3+}$. Here, "Control" is the fluorescence spectra of compound 1 without using any metal-ion modification.
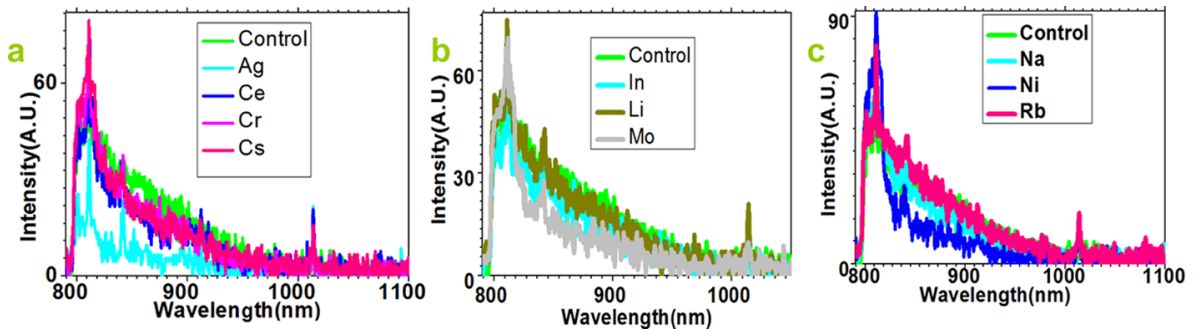

Figure 6. Impact of modification by various metal ions for near-infrared fluorescence of compound 1 is examined: (a) $\mathrm{Ag}^{+}, \mathrm{Ce}^{4+}, \mathrm{Cr}^{3+}, \mathrm{and} \mathrm{Cs}^{+} ;(\mathrm{b}) \mathrm{In}^{+}$, $\mathrm{Li}^{+}$, and $\mathrm{Mo}^{6+} ;(\mathrm{c}) \mathrm{Na}^{+}, \mathrm{Ni}^{3+}$, and $\mathrm{Rb}^{+}$. Here, "Control" is its fluorescence spectra without using any metal-ion modification.

results prove that $\mathrm{Ag}^{+}, \mathrm{Ce}^{4+}, \mathrm{Cr}^{3+}, \mathrm{Cs}^{+}, \mathrm{In}^{+}, \mathrm{Li}^{+}, \mathrm{Mo}^{6+}, \mathrm{Na}^{+}, \mathrm{Ni}^{3+}$, and $\mathrm{Rb}^{+}$ions are not good for the modification of compound $\mathbf{1}$ in order to enhance the NIR fluorescence.

An optical chemistry mechanism is proposed to explain the NIR fluorescence of $\mathrm{Nd}^{3+}$-ion-modified compound $\mathbf{1}$ (see Figure 7). It depicts the energy level transitions of $\mathrm{Nd}^{3+}$-ion- modified compound 1 under $785 \mathrm{~nm}$ light excitation. In this diagram, it is supposed that the $-\mathrm{O}-\mathrm{C}-\mathrm{N}-$ group in compound 1 is excited via absorbing excitation photons. The excited $-\mathrm{O}-\mathrm{C}-\mathrm{N}-$ group is utilized as a sensitizer for the $\mathrm{Nd}^{3+}$ activators. This results in energy transfer from the $-\mathrm{O}-\mathrm{C}-\mathrm{N}-$ group to the $\mathrm{Nd}^{3+}$ ion. As a result, the emission is forced to be 


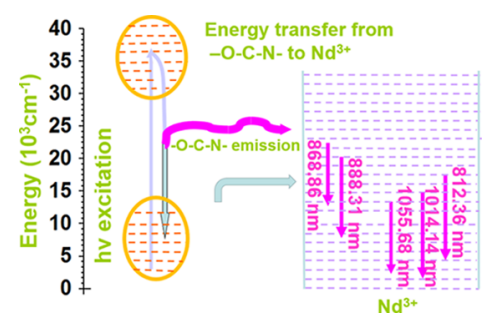

Figure 7. Optical chemistry mechanism of the $\mathrm{Nd}^{3+}$-ion-modified $\mathrm{N}, \mathrm{N}$ dimethyl aspartic acid.

generated. The energy transfer process is described in Figure 7, which results in the emission light of 812.36 (energy level transition happens from ${ }^{2} \mathrm{H}_{11 / 2}$ to $\left.{ }^{4} \mathrm{I}_{13 / 2}\right), 868.86\left({ }^{2} \mathrm{P}_{1 / 2}\right.$ to $\left.{ }^{4} \mathrm{~F}_{3 / 2}\right)$, $888.31\left({ }^{2} \mathrm{G}_{7 / 2}\right.$ to $\left.{ }^{4} \mathrm{I}_{15 / 2}\right), 1014.14\left({ }^{4} \mathrm{~F}_{5 / 2}\right.$ to $\left.{ }^{4} \mathrm{I}_{11 / 2}\right), 1055.68 \mathrm{~nm}$ $\left({ }^{4} \mathrm{~F}_{3 / 2}\right.$ to $\left.{ }^{4} \mathrm{I}_{11 / 2}\right) \cdot{ }^{36}$ The optical chemistry of compound $\mathbf{1}$ modified by other ions under $785 \mathrm{~nm}$ light excitation is similar. The $-\mathrm{O}-\mathrm{C}-\mathrm{N}-$ group works as a sensitizer for the specific metal ion (i.e., $\mathrm{Dy}^{3+}, \mathrm{Gd}^{3+}, \mathrm{Er}^{3+}, \mathrm{Sr}^{2+}, \mathrm{Tl}^{3+}, \mathrm{Y}^{3+}, \mathrm{Zn}^{2+}, \mathrm{Zr}^{4+}, \mathrm{Ho}^{3+}$, $\mathrm{Yb}^{3+}, \mathrm{La}^{3+}, \mathrm{Pr}^{6+} / \mathrm{Pr}^{3+}, \mathrm{Sm}^{3+}, \mathrm{Ag}^{+}, \mathrm{Ce}^{4+}, \mathrm{Cr}^{3+}, \mathrm{Cs}^{+}, \mathrm{In}^{+}, \mathrm{Li}^{+}, \mathrm{Mo}^{6+}$, $\mathrm{Na}^{+}, \mathrm{Ni}^{3+}$, and $\mathrm{Rb}^{+}$ions) activators. The only difference is the emission light and the associated energy level transitions corresponding to the metal ions. The general structure of a laser contains a pumping source, gain medium, and mirrors. While the pumping source and mirrors are commercially available, the gain medium is not always conveniently accessible. The gain medium is the most important factor of the laser as it determines the operation wavelength and optical properties of the laser. Here, single crystals of compound 1 were successfully made. It shows interestingly polychromatic photoluminescence covering an ultrawide range of UV-vis-NIR optical windows. It can be selected as the gain medium to make the laser in specific optical windows. More importantly, it shows NIR fluorescence around $800-1100 \mathrm{~nm}$. The NIR fluorescence intensity can be enhanced, and the emitting wavelength can be shifted when the modification using various metal ions is applied. It indicates that this small molecule can be flexibly utilized as the gain medium for making NIR luminescence lasers covering from 800 to 1100 $\mathrm{nm}$ range. It can be conveniently done via commercial pumping sources such as $785 \mathrm{~nm}$ LDs.

2.5. Enhancement of Dye Photodegradation via Metal-Ion Modification. Figure 8 compares discoloration of the dyes by using compounds $1,2,3$, and 4 . a1, a2, and a 3 are the vials filled with rhodamine $B(\mathrm{RB})$, rhodamine 6G (R6G), and fluorescein sodium salt (FSS) before the discoloration test. Compound 1 was then utilized for running the dye-photodegradation test. b1, b2, and b3 are the vials filled with RB, R6G, and FSS after the discoloration test. It should be noted that the colors of b1, b2, and b3 are almost the same as those of a1, a2, and a3, which indicates that the use of compound $\mathbf{1}$ is not effective for the photodegradation of RB, R6G, and FSS.

Compound 2 was used for the photodegradation test of R6G. $\mathrm{c} 1, \mathrm{c} 2$, and $\mathrm{c} 3$ are the vials filled with R6G after it was carried out with irradiation times of 30,60 , and $80 \mathrm{~min}$. Its color was changed from dark blue to dark yellow after the photodegradation test was completed. When compound 1 was used, the color of R6G was not removed. However, R6G was found to be decolored by compound 2 . Therefore, it suggests that the introduction of $\mathrm{Ca}^{2+}$ ions enhances the ability of R6G photodegradation for the investigated molecule, $\mathrm{N}, \mathrm{N}$-dimethyl aspartic acid. Compounds 3 and 4 were tested for the photodegradation of RB, R6G, and FSS. $d 1, d 2$, and $d 3$ are

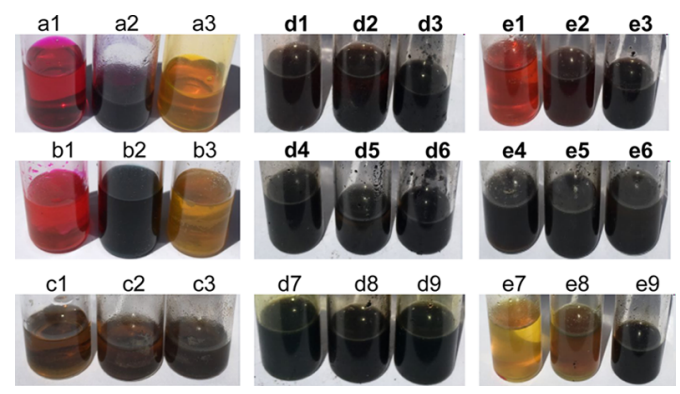

Figure 8. Discoloration of the dyes using photodegradation under white-light irradiation. a1, a2, and a3 are the vials filled with RB, R6G, and FSS before the photodegradation test. b1, b2, and $\mathrm{b} 3$ are the vials filled with RB, R6G, and FSS after the photodegradation test via using compound 1. $\mathrm{c1}, \mathrm{c2}$, and $\mathrm{c} 3$ are the vials filled with R6G after photodegradation tests for 30,60 , and 80 min via using compound 2 . $\mathrm{d} 1, \mathrm{~d} 2$, and $\mathrm{d} 3$ are the vials filled with $\mathrm{RB}$ after photodegradation tests for 20,40 , and 60 min via using compound $3 . \mathrm{d} 4, \mathrm{~d} 5$, and d6 are the vials filled with R6G after photodegradation tests for 20,40 , and $60 \mathrm{~min}$ via compound 3. d7, d8, and $\mathrm{d} 9$ are the vials filled with FSS after photodegradation tests for 20,40 , and 60 min via compound 3. e1, e2, and $\mathrm{e} 3$ are the vials filled with $\mathrm{RB}$ after photodegradation tests for 20 , 40 , and 80 min via compound 4. e4, e5, and e6 are the vials filled with R6G after photodegradation tests for 20,40 , and 80 min via using compound 4. e7, e8, and e9 are the vials filled with FSS after photodegradation tests for 20,40 , and $80 \mathrm{~min}$ via using compound 4 .

the vials filled with $\mathrm{RB}$ after the photodegradation is run for 20 , 40 , and 60 min via using compound $3 . \mathrm{d} 4, \mathrm{~d} 5$, and $\mathrm{d} 6$ are the vials filled with R6G after the photodegradation is run for 20,40 , and 60 min via using compound 3 . $\mathrm{d} 7, \mathrm{~d} 8$, and $\mathrm{d} 9$ are the vials filled with FFS after the photodegradation is performed for 20,40, and 60 min via using compound 3. e1, e2, and e 3 are the vials filled with $\mathrm{RB}$ after the photodegradation test is conducted for 20, 40, and $80 \mathrm{~min}$ via using compound 4. e4, e5, and e6 are the vials filled with R6G after the photodegradation test is run for 20, 40, and $80 \mathrm{~min}$ via using compound 4. e7, e8, and e9 are the vials filled with FSS after the photodegradation is performed for 20, 40 , and 80 min via using compound 4 . The color of RB, R6G, or FSS was successfully removed by using compound 3 or 4 . It indicates that the introduction of $\mathrm{Zr}^{4+}$ or $\mathrm{Sr}^{2+}$ ions to the molecule leads to the degradation of $\mathrm{RB}, \mathrm{R} 6 \mathrm{G}$, and FSS.

The absorption and fluorescence spectra were studied for the impact of compounds $\mathbf{2 , 3}$, and $\mathbf{4}$ on dye photodegradation. The absorption spectral results are shown in Figures S1-S3. The fluorescence spectral analysis is shown as follows.

Figure 9a,b shows the fluorescence spectra corresponding to the photodegradation via compound 2. Figure 9a shows
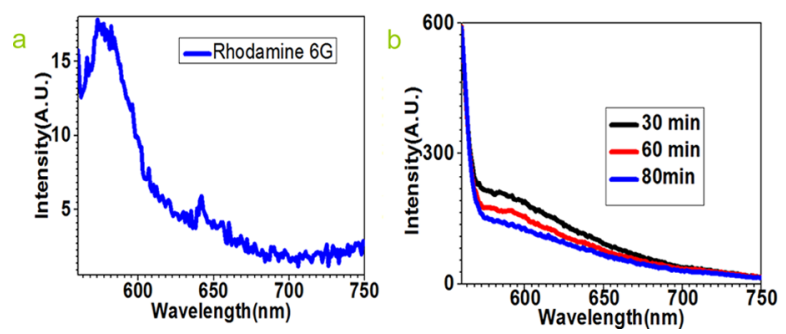

Figure 9. Fluorescence spectral study of the influence of irradiation time under white-light irradiation for R6G after photodegradation test via compound 2. (a) Fluorescence spectra of R6G before photodegradation test. (b) Fluorescence spectral study of the influence of irradiation time. Here, the excitation wavelength is $523 \mathrm{~nm}$. 

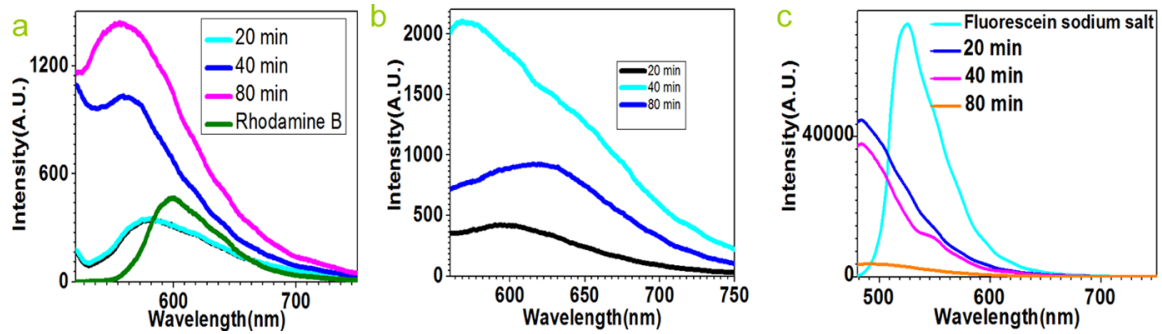

Figure 10. Fluorescence spectral study of the influence of irradiation time under white-light irradiation for dye solutions after photodegradation test via compound 3. (a) Fluorescence spectral study of the influence of irradiation time for photodegradation of RB (excitation wavelength is $480 \mathrm{~nm}$ ). (b) Fluorescence spectral study of the influence of irradiation time for photodegradation of R6G (excitation wavelength is $523 \mathrm{~nm}$ ). (c) Fluorescence spectral study of the influence of irradiation time for photodegradation of FSS (excitation wavelength is $440 \mathrm{~nm}$ ).

fluorescence of pristine R6G, which presents a $573 \mathrm{~nm}$ peak upon $523 \mathrm{~nm}$ light excitation. Figure $9 \mathrm{~b}$ reveals the fluorescence spectra of R6G after photodegradation processing of using compound 2 conducted in 30,60, and $80 \mathrm{~min}$. They all present a shoulder around $570-750 \mathrm{~nm}$. The $573 \mathrm{~nm}$ peak disappears, which suggests the degradation of R6G.

Figure 10a presents the fluorescence spectra of $\mathrm{RB}$ before and after the photodegradation experiment of using compound 3 (the excitation wavelength is $480 \mathrm{~nm}$ ). For pristine RB, it shows a $600 \mathrm{~nm}$ peak (the pink curve in Figure 10a). After the test is run for $20 \mathrm{~min}$, the fluorescence spectra show a peak at $557 \mathrm{~nm}$. After the photodegradation test is conducted for $40 \mathrm{~min}$, a sharp peak centered at $560 \mathrm{~nm}$ appears. After the photodegradation test is performed for $60 \mathrm{~min}$, it shows a small peak around 542 $\mathrm{nm}$.

Figure $10 \mathrm{~b}$ presents the fluorescence of R6G after the photodegradation test through compound 3. The characteristic $573 \mathrm{~nm}$ peak of R6G (as indicated in Figure 9a) is absent in the fluorescence spectra, which means that R6G has been degraded after photodegradation processing is done after 20,40 , and 80 min. The fluorescence spectra for FSS photodegradation with respect to different times are shown in Figure 10c. The fluorescence of pristine FSS shows a characteristic peak at 524 $\mathrm{nm}$ when excited by $440 \mathrm{~nm}$ light (pink curve in Figure 10c). This peak is absent in the fluorescence spectra after the photodegradation test is run for 20,40 , and $80 \mathrm{~min}$, which suggests the degradation of FSS.

The fluorescence spectra corresponding to the photodegradation test via compound $\mathbf{4}$ are revealed in Figure $11 \mathrm{a}-\mathrm{c}$.
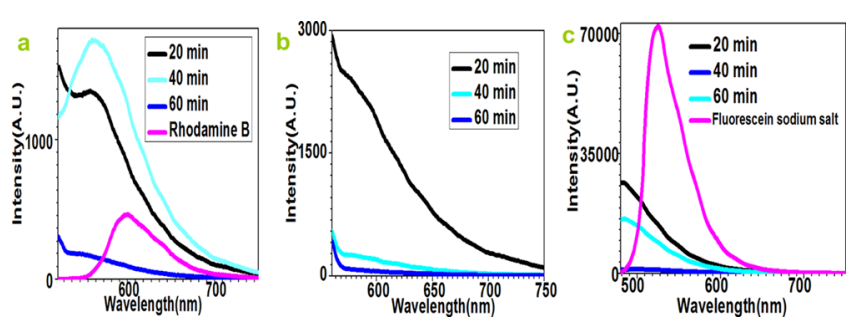

Figure 11. Fluorescence spectral study of the influence of irradiation time under white-light irradiation for dye solutions after photodegradation test via compound 4: (a) Fluorescence spectral study of the influence of irradiation time for the photodegradation of RB (excitation wavelength is $480 \mathrm{~nm}$ ). (b) Fluorescence spectral study of the influence of irradiation time for photodegradation of R6G (excitation wavelength is $523 \mathrm{~nm}$ ). (c) Fluorescence spectral study of the influence of irradiation time for photodegradation of FSS (excitation wavelength is $440 \mathrm{~nm})$.
Figure 11a is the fluorescence spectra of RB excited by $480 \mathrm{~nm}$ light before and after the photodegradation test. For pristine RB, it shows a characteristic $600 \mathrm{~nm}$ peak (the pink curve in Figure 11a). After the photodegradation test via compound 4 is run for $20 \mathrm{~min}$, the fluorescence spectra show a peak at $578 \mathrm{~nm}$. After the photodegradation experiment is run for $40 \mathrm{~min}$, a peak at 557 $\mathrm{nm}$ appears. After the photodegradation test is run for $80 \mathrm{~min}$, it shows a peak around $556 \mathrm{~nm}$.

The characteristic $573 \mathrm{~nm}$ peak of R6G is absent in the fluorescence spectra when the sample is excited by $523 \mathrm{~nm}$ light (see Figure 11b). It indicates the degradation of R6G.

The fluorescence spectra for FSS photodegradation are shown in Figure 11c. The fluorescence of pristine FSS shows a characteristic peak at $524 \mathrm{~nm}$ when excited by $440 \mathrm{~nm}$ light (see the cyan curve in Figure 11c). This peak is found to be absent in the fluorescence spectra after the photodegradation test is run for 20, 40, and $60 \mathrm{~min}$. This suggests the degradation of FSS.

2.6. Mechanism of the Photodegradation. $\mathrm{Ca}^{2+}-, \mathrm{Zr}^{4+}$, or $\mathrm{Sr}^{2+}$-ion-modified aspartic acid showed better photodegradation activities, likely due to the effects of increased electron-hole recombination and reduced material defects. The proposed mechanism for the photodegradation of the dyes can be assumed as (reactions 1-6): under white-light irradiation, the excited electrons and holes diffuse to the sample surface (reaction 1) and react with surface species. With metal-ionmodified aspartic acid (MIMAA), the surface charges become more positive, leading to more $\mathrm{OH}^{-}$ions adsorbed on the material surface for charge balance. The adsorbed $\mathrm{OH}^{-}$ions can accept holes to form hydroxyl radicals ( $\mathrm{OH}$ ) (reaction 3 ). It should be noted that the hole sites attack the adsorbed dye molecules directly (reaction 2), while $\mathrm{OH}$ radicals attack the oxygenated structure (reaction 4) to form dye fragments. Subsequently, the dye fragments react with the active sites, including holes and $\mathrm{OH}$ radicals (reactions 5 and 6). For this reason, more absorption sites of the $\mathrm{n}-\pi^{*}$ transition are formed at the initial stage due to the $\mathrm{OH}$ attack.

$$
\begin{aligned}
& \text { MIMAA }+ \text { photon } \rightarrow \mathrm{h}^{+}+\mathrm{e}^{-} \\
& \text {dye }_{\text {adsorbed }}^{-}+\mathrm{h}^{+} \rightarrow \mathrm{CO}_{2}+\mathrm{H}_{2} \mathrm{O} \\
& \mathrm{OH}_{\text {adsorbed }}^{-}+\mathrm{h}^{+} \rightarrow \mathrm{OH} \\
& (\text { phenyl }-\mathrm{O}-\mathrm{R})+\mathrm{OH}+\mathrm{H}^{+} \\
& \quad \rightarrow(\text { phenyl }-\mathrm{OH})+(\mathrm{HO}-\mathrm{R}) \\
& (\text { phenyl }-\mathrm{OH})+\mathrm{h}^{+} \text {or } \mathrm{OH} \rightarrow \mathrm{CO}_{2}+\mathrm{H}_{2} \mathrm{O} \\
& (\mathrm{HO}-\mathrm{R})+\mathrm{h}^{+} \text {or } \mathrm{OH} \rightarrow \mathrm{CO}_{2}+\mathrm{H}_{2} \mathrm{O}
\end{aligned}
$$




\section{CONCLUSIONS}

A new type of aspartic acid single crystal, compound $\mathbf{1}$, has been synthesized.

The enhanced NIR photoluminescence of the neodymium ion has been achieved from the neodymium-ion-associated compound 1 sensitized by the $-\mathrm{O}-\mathrm{C}-\mathrm{N}-$ group upon $785 \mathrm{~nm}$ excitation. The results suggest that it has promising applications in neodymium-based optical materials and devices. Indirect excitation mechanisms for the investigated $\mathrm{Nd}^{3+}$-modified compound $\mathbf{1}$ are deduced mainly to be $-\mathrm{O}-\mathrm{C}-\mathrm{N}-$ group emission introduced energy transition from ${ }^{2} \mathrm{H}_{11 / 2}$ to ${ }^{4} \mathrm{I}_{13 / 2}$ (for $812.36 \mathrm{~nm}$ light emission), ${ }^{2} \mathrm{P}_{1 / 2}$ to ${ }^{4} \mathrm{~F}_{3 / 2}$ (for $868.86 \mathrm{~nm}$ emission), ${ }^{2} \mathrm{G}_{7 / 2}$ to ${ }^{4} \mathrm{I}_{15 / 2}$ (for $888.31 \mathrm{~nm}$ emission), ${ }^{4} \mathrm{~F}_{5 / 2}$ to ${ }^{4} \mathrm{I}_{11 / 2}$ (for $1014.14 \mathrm{~nm}$ light emission), and $1055.68{ }^{4} \mathrm{~F}_{3 / 2}$ to ${ }^{4} \mathrm{I}_{11 / 2}$ (for $1055.68 \mathrm{~nm}$ light emission). Further work is in progress concerning much evidence for the optical chemistry mechanisms. Also, the intensified NIR luminescence of the $\mathrm{Dy}^{3+}-, \mathrm{Gd}^{3+}-, \mathrm{Nd}^{3+}-, \mathrm{Er}^{3+}-, \mathrm{Sr}^{2+}-, \mathrm{Tl}^{3+}-, \mathrm{Y}^{3+}-, \mathrm{Zn}^{2+}-, \mathrm{Zr}^{4+}-, \mathrm{Ho}^{3+}$, $\mathrm{Yb}^{3+}-, \mathrm{La}^{3+}-, \mathrm{Pr}^{6+} / \mathrm{Pr}^{3+}-, \mathrm{Sm}^{3+}$-modified compound 1 pumped at $785 \mathrm{~nm}$ provides the possibility to incorporate it into polymers or hybrid organic-inorganic matrixes to fabricate the excitation medium for the NIR laser.

In addition, compound $\mathbf{2}\left(\mathrm{Ca}^{2+}\right.$-ion-modified compound $\left.\mathbf{1}\right)$ is found to be useful for the photodegradation of rhodamine 6G. Compounds $3\left(\mathrm{Zr}^{4+}\right.$-modified compound 1$)$ and $4\left(\mathrm{Sr}^{2+}\right.$ modified compound 1) are good for the photodegradation of rhodamine $\mathrm{B}$, rhodamine $6 \mathrm{G}$, and fluorescein sodium salt. These indicate that metal-ion modification is a good way for increasing the ability of dye photodegradation for the studied molecule.

This work shows development of a new small molecule whose NIR luminescence and ability of dye degradation can be simultaneously enhanced by the association of metal ions.

We are currently experimenting with modified ligands to determine whether the aspartic acid complexes can be made reactive with other compounds, such as $\mathrm{CO}_{2}$, through metal-ion modification; these changes are designed to develop the small molecule into a robust material system with more functionalities.

\section{EXPERIMENTAL SECTION}

4.1. Materials. All commercially available reagents and solvents were bought from Alfa Aesar and used without further purification.

4.2. Preparation of Organic Complex Solution. Solution a was made by dissolving 2 -methylimidazole $(2 \mathrm{~g})$, terephthalic acid $(5 \mathrm{~g})$, fumaric acid $(5 \mathrm{~g}), \mathrm{D}-(+)$-glucose $(5 \mathrm{~g})$, oxalic acid dihydrate $(5 \mathrm{~g})$, and dimethyl sulfoxide $(50 \mathrm{~mL})$ in deionized water $(200 \mathrm{~mL})$. Solution $\mathrm{b}$ was prepared by mixing dimethylformamide $(300 \mathrm{~mL})$, oleic acid $(40 \mathrm{~mL})$, triethylamine $(40 \mathrm{~mL})$, diethylene glycol $(40 \mathrm{~mL})$, dimethyl sulfoxide $(20 \mathrm{~mL})$, and methacrylic anhydride $(10 \mathrm{~mL})$. Solution $\mathrm{c}$ was made by dissolving L-cysteine $(2 \mathrm{~g})$ in deionized water $(50 \mathrm{~mL})$. Solutions $\mathrm{a}, \mathrm{b}$, and $\mathrm{c}$ were mixed and stirred to get the organic complex solution.

4.3. Preparation of Racemic $N, N$-Dimethyl Aspartic Acid. Niobium $(\mathrm{V})$ chloride $(0.1 \mathrm{~g})$, samarium chloride hydrate $(0.4 \mathrm{~g})$, and sodium hydroxide $(0.016 \mathrm{~g})$ were dissolved in deionized water $(10 \mathrm{~mL})$ to get solution $\mathrm{d}$. Solution d was mixed with $40 \mathrm{~mL}$ of organic complex solution prepared in the previous step. The acquired solution was heated with $80^{\circ} \mathrm{C}$ for $2 \mathrm{~h}$. The acquired yellow-black crystals were cleaned with ethanol. Then the crystals were recrystallized in ethanol for single-crystal X-ray diffraction measurement.
4.4. Preparation of Metal-Ion-Modified $N, N$-Dimethyl

Aspartic Acid. The synthesized sample of racemic $N, N$ dimethyl aspartic acid (0.1 g) was dissolved in methanol (50 $\mathrm{mL}$ ) to get solution $\mathrm{d}$.

Zirconium(IV) chloride $(0.12 \mathrm{~g})$ was first dissolved in water $(1 \mathrm{~mL})$. Then the acquired $\mathrm{Zr}^{4+}$-ion solution was added to solution $\mathrm{d}(1 \mathrm{~mL})$ in a centrifuge tube, which was shaken for 5 min to get $\mathrm{Zr}^{4+}$-ion-modified $N, N$-dimethyl aspartic acid.

The preparation of $\mathrm{Ca}^{2+}-, \mathrm{Dy}^{3+}-, \mathrm{Gd}^{3+}-, \mathrm{Nd}^{3+}-, \mathrm{Er}^{3+}-, \mathrm{Sr}^{2+}$, $\mathrm{Tl}^{3+}-, \mathrm{Y}^{3+}-, \mathrm{Zn}^{2+}-, \mathrm{Zr}^{4+}-, \mathrm{Ho}^{3+}-, \mathrm{Yb}^{3+}-, \mathrm{La}^{3+}-, \mathrm{Pr}^{6+} / \mathrm{Pr}^{3+}-, \mathrm{Sm}^{3+}$, $\mathrm{Ag}^{+}-, \mathrm{Ce}^{4+}-, \mathrm{Cr}^{3+}-, \mathrm{Cs}^{+}-, \mathrm{In}^{+}-, \mathrm{Li}^{+}-, \mathrm{Mo}^{6+}-, \mathrm{Na}^{+}-$, and $\mathrm{Ni}^{3+}-$ ionmodified $N, N$-dimethyl aspartic acid is similar to that of $\mathrm{Zr}^{4+}$ ion-modified $N, N$-dimethyl aspartic acid.

4.5. Characterization and Optical Study. The XPS study was performed by using a K-Alpha XPS instrument (Thermo Scientific). Single-crystal X-ray diffraction measurement was done through a Bruker APEX3 diffractometer. UV-vis-NIR absorption and UV-vis fluorescence spectroscopy were collected through a SPARK spectrometer. The FTIR spectra were collected via a Thermo Fisher Nicolet IS 10 Fourier transform infrared (FTIR) spectrometer equipped with a Smart iTR diamond ATR accessory and with a deuterated triglycine sulfate detector. The mass spectra were collected through an accurate mass electrospray ionization (ESI) mass spectrometer coupled with a high-performance liquid chromatograph (HPLC). Specifically, an Agilent 1260 Infinity II quaternary liquid chromatograph coupled to an Agilent 6230 electrospray time-of-flight mass spectrometer was used for detection of analytes. NMR spectra were collected via a Bruker AV-400 MHz spectrometer. Deuterated dimethyl sulfoxide (DMSO- $d_{6}$ ) was used as a solvent for NMR.

A commercial SPARK spectrometer was used to collect the absorption spectra. The fluorescence spectra corresponding to excitation light wavelengths of 280, 310, 320, 340, 350, 360, 440, 540 , and $610 \mathrm{~nm}$ were also collected through the SPARK spectrometer.

For collecting NIR fluorescence, a laser diode (center wavelength $=785 \mathrm{~nm}$, Thermal Scientific, Inc.) was used as the excitation light source. An optical fiber bundle was used to deliver a laser power of $20 \mathrm{~mW}$. Another optical fiber bundle was moving around the sample surface to collect the NIR fluorescence. An NIR long-pass filter was set in front of an NIR spectrometer (Ocean Optics, Inc.) to get rid of the excitation light. A lens was used to focus the collected fluorescence into the inlet of the NIR spectrometer.

4.6. Photodegradation Experiment. Fluorescein sodium salt $(0.1 \mathrm{~g})$ was dissolved in deionized water $(50 \mathrm{~mL})$ to obtain the solution FSS. Rhodamine 6G $(0.1 \mathrm{~g})$ was dissolved in ethanol $(50 \mathrm{~mL})$ to acquire the R6G solution. Rhodamine $\mathrm{B}$ $(0.53 \mathrm{~g})$ was dissolved in deionized water $(100 \mathrm{~mL})$ to get the $\mathrm{RB}$ solution. Calcium chloride $(1.3 \mathrm{~g})$ was mixed with water $(10$ $\mathrm{mL}$ ) to get the $\mathrm{Ca}^{2+}$ solution (solution 1$)$. Compound $\mathbf{1}(0.2 \mathrm{~g}$ ) was added to solution 1 and stirred to get solution 2 . Solution 2 $(1.5 \mathrm{~mL})$ was mixed with R6G $(500 \mu \mathrm{L})$ and stirred to get solution 3. A halogen light bulb (Model: Double Ended Quartz FCL, OSRAM) with a maximum output optical power of $500 \mathrm{~W}$ was utilized for white-light irradiation. The output optical power of the light bulb is controlled by a self-built controller. Solution 3 was irradiated by white light for 30,60 , and $80 \mathrm{~min}$. The irradiated solution 3 was taken to an optical spectrometer for optical absorption and fluorescence measurement. The procedures of the photodegradation of $\mathrm{RB}, \mathrm{R} 6 \mathrm{G}$, and FSS through compounds 3 and 4 are similar. 


\section{ASSOCIATED CONTENT}

\section{S Supporting Information}

The Supporting Information is available free of charge on the ACS Publications website at DOI: 10.1021/acsomega.9b02434.

Crystallographic data for racemic $N, N$-dimethyl aspartic acid (CIF)

Absorption spectra of dye solutions after the photodegradation test (Figures S1-S3) (PDF)

\section{Accession Codes}

The X-ray crystallographic coordinates for structures reported in this article have been deposited at the Cambridge Crystallographic Data Centre (CCDC), under deposition numbers CCDC 1904827. These data can be obtained free of charge from The Cambridge Crystallographic Data Centre via www.ccdc. cam.ac.uk/data_request/cif.

\section{AUTHOR INFORMATION}

\section{Corresponding Authors}

*E-mail: linyc@cqu.edu.cn (Y.L.).

*E-mail: huiminwen@zjut.edu.cn (H.-M.W.).

*E-mail: jianxu1@lsu.edu (J.X.).

\section{ORCID}

Ye Wu: 0000-0002-4831-9729

Pengfei Ou: 0000-0002-3630-0385

Frank R. Fronczek: 0000-0001-5544-2779

Jun Song: 0000-0003-3675-574X

\section{Author Contributions}

${ }^{\nabla}$ Y.W., P.O., and F.R.F. contributed equally.

\section{Notes}

The authors declare no competing financial interest.

\section{ACKNOWLEDGMENTS}

The authors gratefully acknowledge the financial support from China National Key R\&D Program (2017YFB1103202), Jiangsu State R\&D Program(BE2018010), LSU Leveraging Innovation for Technology Transfer (LIFT2) Grant LSU-2019LIFT-003, Louisiana Research Competitiveness Subprogram(RCS), Board of Regents Support Fund (BoRSF) LEQSF (2018-21)-RD-A-09, and LSU Biomedical Collaborative Research Program (008481). The valuable advices from Dr. Yunqi Liu at Albemarle Corporation are much appreciated.

\section{REFERENCES}

(1) Xu, J.; Kooby, D.; Kairdolf, B.; Nie, S. New horizons in intraoperative diagnostics of cancer in image and spectroscopy guided pancreatic cancer surgery. New Horiz. Clin. Case Rep. 2017, 1, 2.

(2) Xu, J.; Kooby, D.; Nie, S. Nanofluorophore Assisted Fluorescence Image-guided Cancer Surgery. J. Med. Clin. Res. Rev. 2018, 2, 1-3.

(3) Li, Z.; Yao, S.; Xu, J.; Wu, Y.; Li, C.; He, Z. Endoscopic NearInfrared Dental Imaging with Indocyanine Green: a Pilot Study. Ann. N. Y. Acad. Sci. 2018, 1421, 88-96.

(4) Wu, Y.; Lin, Y.; Xu, J. Synthesis of Ag-Ho, Ag-Sm, Ag-Zn, Ag-Cu, $\mathrm{Ag}-\mathrm{Cs}, \mathrm{Ag}-\mathrm{Zr}, \mathrm{Ag}-\mathrm{Er}, \mathrm{Ag}-\mathrm{Y}$ and Ag-Co metal organic nanoparticles for UV-Vis-NIR wide-range bio-tissue imaging. Photochem. Photobiol. Sci. 2019, 18, 1081-1091.

(5) Kam, N. W. S.; O’Connell, M.; Wisdom, J. A.; Dai, H. Carbon nanotubes as multifunctional biological transporters and near-infrared agents for selective cancer cell destruction. PNAS 2005, 102, 1160011605 .

(6) Gao, X.; Cui, Y.; Levenson, R. M.; Chung, L. W. K.; Nie, S. In vivo cancer targeting and imaging with semiconductor quantum dots. Nat. Biotech. 2004, 22, 969-976.
(7) Taniguchi, S.; Green, M.; Rizvi, S. B.; Seifalian, A. The one-pot synthesis of core/shell/shell $\mathrm{CdTe} / \mathrm{CdSe} / \mathrm{ZnSe}$ quantum dots in aqueous media for in vivo deep tissue imaging. J. Mater. Chem. 2011, 21, $2877-2882$.

(8) Chen, B.; Yang, Y.; Zapata, F.; Qian, G.; Luo, Y.; Zhang, J.; Lobkovsky, E. B. Enhanced near-infrared-luminescence in an erbium tetrafluoroterephthalate framework. Inorg. Chem. 2006, 45, 88828886.

(9) Antaris, A. L.; Chen, H.; Cheng, K.; Sun, Y.; Hong, G.; Qu, C.; Diao, S.; Deng, Z.; Hu, X.; Zhang, B.; Zhang, X.; Yaghi, O. K.; Alamparambil, Z. R.; Hong, X.; Cheng, Z.; Dai, H. A small-molecule dye for NIR-II imaging. Nat. Mater. 2016, 15, 235-242.

(10) Zha, Z.; Deng, Z.; Li, Y.; Li, C.; Wang, J.; Wang, S.; Qu, E.; Dai, Z. Biocompatible polypyrrole nanoparticles as a novel organic photoacoustic contrast agent for deep tissue imaging. Nanoscale 2013, 5 , $4462-4467$.

(11) Welsher, K.; Sherlock, S. P.; Dai, H. Deep-tissue anatomical imaging of mice using carbon nanotube fluorophores in the second near-infrared window. PNAS 2011, 108, 8943-8948.

(12) Ju, H.; Roy, R. A.; Murray, T. W. Gold nanoparticle targeted photoacoustic cavitation for potential deep tissue imaging and therapy. Biomed. Opt. Express 2013, 4, 66-76.

(13) Ku, G.; Zhou, M.; Song, S.; Huang, Q.; Hazle, J.; Li, C. Copper sulfide nanoparticles as a new class of photoacoustic contrast agent for deep tissue imaging at $1064 \mathrm{~nm}$. ACS Nano 2012, 6, 7489-7496.

(14) Li, Y.; Zhou, S.; Li, Y.; Sharafudeen, K.; Ma, Z.; Dong, G.; Peng, M.; Qiu, J. Long persistent and photo-stimulated luminescence in $\mathrm{Cr}^{3+}$-doped $\mathrm{Zn}-\mathrm{Ga}-\mathrm{Sn}-\mathrm{O}$ phosphors for deep and reproducible tissue imaging. J. Mater. Chem. C 2014, 2, 2657-2663.

(15) Sandros, M. G.; Behrendt, M.; Maysinger, D.; Tabrizian, M. InGaP@ZnS-Enriched Chitosan Nanoparticles: A Versatile Fluorescent Probe for Deep-Tissue Imaging. Adv. Funct. Mater. 2007, 17, 3724-3730.

(16) Chen, H.; Qi, B.; Moore, T.; Colvin, D. C.; Crawford, T.; Gore, J. C.; Alexis, F.; Mefford, O. T.; Anker, J. N. Synthesis of brightly PEGylated luminescent magnetic upconversion nanophosphors for deep tissue and dual MRI imaging. Small 2014, 10, 160-168.

(17) Chuang, Y.-J.; Zhen, Z.; Zhang, F.; Liu, F.; Mishra, J. P.; Tang, W.; Chen, H.; Huang, X.; Wang, L.; Chen, X.; Xie, J.; Pan, Z. Photostimulable near-infrared persistent luminescent nanoprobes for ultrasensitive and longitudinal deep-tissue bio-imaging. Theranostics 2014, 4, 1112-1122.

(18) Levy, E. S.; Tajon, C. A.; Bischof, T. S.; Iafrati, J.; FernandezBravo, A.; Garfield, D. J.; Chamanzar, M.; Maharbiz, M. M.; Sohal, V. S.; Schuck, P. J.; Cohen, B. E.; Chan, E. M. Energy-looping nanoparticles: harnessing excited-state absorption for deep-tissue imaging. ACS Nano 2016, 10, 8423-8433.

(19) Chen, G.; Shen, J.; Ohulchanskyy, T. Y.; Patel, N. J.; Kutikov, A.; Li, Z.; Song, J.; Pandey, R. K.; Ågren, H.; Prasad, P. N.; Han, G. $(\alpha-$ $\left.\mathrm{NaYbF}_{4}: \mathrm{Tm}^{3+}\right) / \mathrm{CaF}_{2}$ core/shell nanoparticles with efficient nearInfrared to near-Infrared upconversion for high-contrast deep Tissue Bioimaging. ACS Nano 2012, 6, 8280-8287.

(20) Zhang, J.; Wang, H.; Yang, S.; Wang, S.; Yang, S. Enhanced conductivity and fluorescence of polyaniline doped with $\mathrm{Eu}^{3+}, \mathrm{Tb}^{3+}$, and $\mathrm{Y}^{3+}$ ions. J. Appl. Polym. Sci. 2012, 125, 2494-2501.

(21) Mahata, M. K.; Tiwari, S. P.; Mukherjee, S.; Kumar, K.; Rai, V. K. $\mathrm{YVO}_{4}: \mathrm{Er}^{3+} / \mathrm{Yb}^{3+}$ phosphor for multifunctional applications. J. Opt. Soc. Am. B 2014, 31, 1814-1821.

(22) Jie, G.; Zhao, G.; Wang, J.; Han, G. Energy transfer and frequency upconversion in $\mathrm{Er}^{3+}-\mathrm{Yb}^{3+}$ codoped oxy-fluoro-tungstosilicate glasses. J. Rare Earths 2012, 30, 422-425.

(23) Xiang, G.; Zhang, J.; Hao, Z.; Zhang, X.; Pan, G.-H.; Luo, Y.; $Z$ hao, $\mathrm{H}$. Decrease in particle size and enhancement of upconversion emission through $\mathrm{Y}^{3+}$ ions doping in hexagonal $\mathrm{NaLuF}_{4}: \mathrm{Yb}^{3+} / \mathrm{Er}^{3+}$ nanocrystals. CrystEngComm 2015, 17, 3103.

(24) Tanimura, K.; Shinn, M. D.; Sibley, W. A.; Drexhage, M. G.; Brown, R. N. Optical transitions of $\mathrm{Ho}^{3+}$ ions in fluorozirconate glass. Phys. Rev. B 1984, 30, 2429-2437. 
(25) Lin, H.; Chen, D.; Yu, Y.; Yang, A.; Wang, Y. Near-infrared quantum cutting in $\mathrm{Ho}^{3+} / \mathrm{Yb}^{3+}$ codoped nanostructured glass ceramic. Opt. Lett. 2011, 36, 876-878.

(26) Capobianco, J. A.; Boyer, J. C.; Vetrone, F.; Speghini, A.; Bettinelli, M. Optical spectroscopy and upconversion studies of $\mathrm{Ho}^{3+}$ doped bulk and nanocrystalline $\mathrm{Y}_{2} \mathrm{O}_{3}$. Chem. Mater. 2002, 14, 29152921.

(27) Shakeri, M. S.; Rezvani, M. Optical band gap and spectroscopic study of lithium alumino silicate glass containing $\mathrm{Y}^{3+}$ ions. Spectrochim. Acta, Part A 2011, 79, 1920-1925.

(28) Chibata, I.; Tosa, T.; Sato, T. Continuous Production of LAspartic Acid. Appl. Biochem. Biotechnol. 1986, 13, 231-240.

(29) Man, E. H.; Fisher, G. H.; Payan, I. L.; Cadilla-Perezrios, R.; Garcia, N. M.; Chemburkar, R.; Arends, G.; Frey, W. H., II D-Aspartate in Human Brain. J. Neurochem. 1987, 48, 510-515.

(30) Wu, Y.; Fu, H.; Xie, W.; Lin, Y.; Kizilkaya, O.; Xu, J. 3D Macroporous Zinc Compound/Silicone Hybrid Foams for Amperometric Sensing of Glucose Oxidase. Global Challenges 2019, 3, 1800049.

(31) Wu, Y.; Fu, H.; Roy, A.; Song, P.; Lin, Y.; Kizilkaya, O.; Xu, J. Facile one-pot synthesis of $3 \mathrm{D}$ graphite- $\mathrm{SiO}_{2}$ composite foam for negative resistance devices. RSC Adv. 2017, 7, 41812-41818.

(32) Wu, Y.; Fu, H.; Zhang, L.; Lin, Y.; Kizilkaya, O.; Xu, J. Toward a rapid-fabricated triboelectric Device with a 1,3-Phosphorylated Poly(vinyl alcohol) polymer for water turbulence energy harvesting. ACS Omega 2018, 3, 8421-8428.

(33) Navarrete, J. T. L.; Hernández, V.; Ramírez, F. J. IR and Raman Spectra of L-Aspartic Acid and Isotopic Derivatives. Biopolymers 1994, 34, 1065-1077.

(34) Naresh Chary, V.; Sudarshana Reddy, B.; Kumar, C. D.; Srinivas, R.; Prabhakar, S. Characterization of N,N-dimethyl amino acids by electrospray ionization-tandem mass spectrometry. J. Mass Spectrom. 2015, 50, 771-781.

(35) Kotiaho, T.; Eberlin, M. N.; Vainiotalo, P.; Kostiainen, R. Electrospray mass and tandem mass spectrometry identification of ozone oxidation products of amino acids and small peptides. J. Am. Soc. Mass Spectrom. 2000, 11, 526-535.

(36) Gruber, J. B.; Hills, M. E.; Allik, T. H.; Jayasankar, C. K.; Quagliano, J. R.; Richardson, F. S. Comparative analysis of $\mathrm{Nd}^{3+}\left(4 \mathrm{f}^{3}\right)$ energy levels in four garnet hosts. Phys. Rev. B 1990, 41, 7999-8012. 